\title{
PERANAN NUMBER HEADS TOGETHER DALAM PEMBELAJARAN BIOLOGI DI KELAS XI IPA
}

\author{
Ernita Rahmaniati \\ SMA NEGERI 4 PONTIANAK \\ errahmaniati@gmail.com
}

\begin{abstract}
This research motivated presence of symptoms that can be seen in the field that the biological activity and learning outcomes have not achieved the expected result of 78. The cause of the low biological activity and learning outcomes is presumably because the teacher actively describes the material, give examples, and exercises while students just listen, take notes, and do the exercises. Learning as it failed to give students the chance to discover, establish and develop his own knowledge. This type of research is done in an attempt repair of the problems mentioned above is a Classroom Action Research. Data of this research is taken using an instrument tests, observation sheet and evaluation test results are processed in a qualitative study. The results showed that by using cooperative learning type Number Heads Together can increase the activity of learning and learning outcomes of students of class XI IPA1 SMA 4 Pontianak.

Keywords : Activity, learning outcomes, Number Heads Together.
\end{abstract}

\begin{tabular}{|c|c|}
\hline \multicolumn{2}{|l|}{ Mata pelajaran Biologi } \\
\hline \multirow{12}{*}{$\begin{array}{l}\text { diajarkan pada tingkat sekolah } \\
\text { menengah atas (SMA) untuk } \\
\text { membekali peserta } \\
\text { pengetahuan, didik } \\
\text { sejumlah kemahaman, dan } \\
\text { memasuki jenjang pendidikan yang } \\
\text { lebih tinggi serta mengembangkan } \\
\text { ilmu dan teknologi. Secara umum } \\
\text { diketahui bahwa kegiatan belajar } \\
\text { mengajar akan berhasil apabila terjadi } \\
\text { perubahan tingkah laku pada anak } \\
\text { didik sesuai dengan tujuan yang ingin } \\
\text { dicapai. }\end{array}$} & Anitah (2008:1.12) \\
\hline & bahwa \\
\hline & $\begin{array}{l}\text { mengaktifkan siswa belajar, gurt } \\
\text { harus berusaha meningkatkan kada }\end{array}$ \\
\hline & aktivitas belajar tersebut. Itula \\
\hline & sebabnya aktivitas mert \\
\hline & \\
\hline & erat \\
\hline & Sardim \\
\hline & bahwa \\
\hline & diperlukan adanya aktivitas. $\mathrm{Be}$ \\
\hline & juga dengan Wina sanjaya (2008: \\
\hline & mengatakan \\
\hline Perubahan tingkah laku yang & belajar harus \\
\hline sud dapat terjadi a & aktivitas siswa. Sejalan der \\
\hline es pembe & $\begin{array}{l}\text { dapat } \mathrm{d} \\
\text { vitas dalar }\end{array}$ \\
\hline $\begin{array}{l}\text { tivitas fisik, mental, maupun } \\
\text { nosional. Mengapa dalam belajar }\end{array}$ & $\begin{array}{l}\text { tivitas dalam pembelajaran } \mathrm{j} \\
\text { gkapkan oleh T.Raka Joni ( } 1\end{array}$ \\
\hline perlukan aktivitas? Sebab pada & menyatakan bahwa \\
\hline pnya belajar & dalam \\
\hline tuk & pembelajaran \\
\hline & \\
\hline
\end{tabular}


akan adanya asimilasi kognitif, akomodasi kognitif, feed back (balikan) dan internalisasi nilai-nilai. Oleh karena itu, pembelajaran Biologi menekankan pada pemberian pengalaman belajar secara langsung melalui penggunaan dan pengembangan keterampilan proses dan sikap ilmiah (BSNP, Depdiknas: 2006). Dengan demikian, secara umum kompetensi bahan kajian ilmu Biologi meliputi dua aspek, yaitu aspek pemahaman konsep (hasil belajar) dan penerapannya serta aspek kerja ilmiah (aspek aktivitas belajar). Dari hasil penilaian guru diketahui bahwa aktivitas dan hasil belajar siswa pada materi sistem pencernaan makanan masih rendah.

Rendahnya prestasi belajar Biologi di kelas tersebut diduga karena guru secara aktif menjelaskan materi, memberi contoh, dan latihan sedangkan siswa hanya mendengar, mencatat, dan mengerjakan latihan. Pembelajaran seperti itu kurang memberikan kesempatan kepada siswa untuk menemukan, membentuk, dan mengembangkan pengetahuannya sendiri. Selain itu, kecil sekali peluang terjadinya proses sosial antar siswa yaitu hubungan siswa satu dengan siswa lainnya dalam rangka membangun pengetahuan bersama.

Selama bertugas sebagai guru Biologi pada SMAN 4 Pontianak, peneliti mendapatkan hasil ulangan siswa belum memuaskan, khususnya pada materi sistem pencernaan makanan. Hasil ulangan harian siswa tersebut belum mencapai kriteria ketuntasan minimal (KKM), yaitu 78 . Hasil ulangan siswa kelas XI IPA1 SMAN 4 Pontianak tahun pelajaran 2012 - 2013 rendah dibandingkan dengan kelas XI IPA lainnya, ditandai dengan hasil ulangan harian pada meteri sistem pencernaan makanan hanya mencapai rata-rata kelas sebesar 56,95 atau sebanyak 32\% siswa dari 38 siswa dikelas tersebut yang telah mencapai nilai ketuntasan 78.

$\begin{array}{rrr}\text { Setelah } & \text { peneliti } & \text { melakukan } \\ \text { refleksi, } & \text { maka } & \text { diduga }\end{array}$ ketidaktercapaian ini disebabkan aktivitas belajar siswa masih rendah. Dalam praktik pembelajaran, peneliti lebih banyak aktif dari pada siswa, sehingga pembelajaran lebih didominasi oleh peneliti. Peneliti juga merefleksi diri mengenai pembelajaran yang diterapkan selama ini masih bersifat konvensional. Hal ini menyebabkan kelas cenderung pasif, sehingga hanya terjadi pemberian informasi dari peneliti ke siswa (teacher oriented).

Berangkat dari hal tersebut peneliti mencoba untuk memperbaiki proses belajar mengajar sebagai upaya meningkatkan aktivitas dan hasil belajar siswa, satu alternatif pemecahannya adalah dengan penerapan model pembelajaran kooperatif tipe Number Heads Together (NHT).

Adapun tujuan dari penelitian tindakan kelas ini adalah (1) Mengetahui dan menganalisis kegiatan setiap siklus dalam proses pembelajaran Biologi dengan penerapan model pembelajaran kooperatif tipe Number Heads Together di kelas XI IPA1 SMA Negeri 4 Pontianak tahun pelajarn 2013 - 2014; (2) Memperoleh informasi ada tidaknya peningkatan aktivitas belajar terkait penggunaan dengan penerapan model pembelajaran kooperatif tipe Number 
Heads Together di kelas X IPA1 SMA Negeri 4 Pontianak tahun pelajaran 2013 - 2014; dan (3) Memperoleh informasi ada tidaknya peningkatan hasil belajar siswa terkait dengan penerapan model pembelajaran kooperatif tipe Number heads together di kelas XI IPA1 SMA Negeri 4 Pontianak tahun pelajaran 2013 - 2014.

Belajar merupakan suatu proses perubahan yang dilakukan oleh seseorang atau individu, tidak hanya sekedar banyak atau sedikitnya pengetahuan yang dimiliki, namun juga melputi seluruh kemampuan yang dimilikinya. Menurut Winataputra (2007:1.9), belajar harus memungkinkan terjadinya perubahan yang merupakan buah dari pengalaman. Pendapat ini secara jelas memusatkan perhatian mengenai betapa pentingnya aktivitas dalam proses belajar seseorang atau individu.

Aktivitas merupakan suatu kegiatan melakukan atau berbuat. Tidak ada belajar kalau tidak ada aktivitas. Itulah sebabnya aktivitas merupakan prinsip atau asas yang sangat penting di dalam interaksi belajar- mengajar (Sardiman, 2012: 96). Aktivitas belajar yang dilakukan dalam interaksi belajar mengajar meliputi kegiatan timbal balik yang terjadi antara guru dengan siswa, siswa dengan bahan ajar, dan siswa dengan siswa. Menurut Winataputra (2007: 1.5), aktivitas belajar merupakan proses psikologispedagogis yang ditandai dengan adanya interaksi individu dengan lingkungan belajar yang sengaja diciptakan agar siswa berperan aktif dalam kegiatan belajar di kelas. Dengan demikian guru hendaknya merencanakan kegiatan belajar yang memfasilitasi siswa untuk banyak melakukan aktivitas belajar siswa seperti mencari, mengolah, dan melaporkan informasi dari berbagai sumber yang akhirnya dipresentasikan di depan kelas.

\section{Numbered Head Together}

(NHT) pada dasarnya merupakan sebuah varian diskusi kelompok. Ciri khasnya adalah guru hanya menunjuk seorang siswa yang mewakili kelompoknya, tanpa memberi tahu terlebih dahulu siapa yang akan mewakili kelompok itu. Cara ini menjamin keterlibatan total semua siswa, cara ini juga merupakan upaya yang sangat baik untuk meningkatkan tanggung jawab individual dalam diskusi kelompok.

Numbered Head Together (NHT) merupakan suatu pendekatan yang dikembangkan oleh Kagen (dalam Ibrahim et all, 2007:28) untuk melibatkan banyak siswa dalam memperoleh materi yang tercakup dalam suatu pelajaran dan mengecek pemahaman mereka terhadap isi pelajaran.

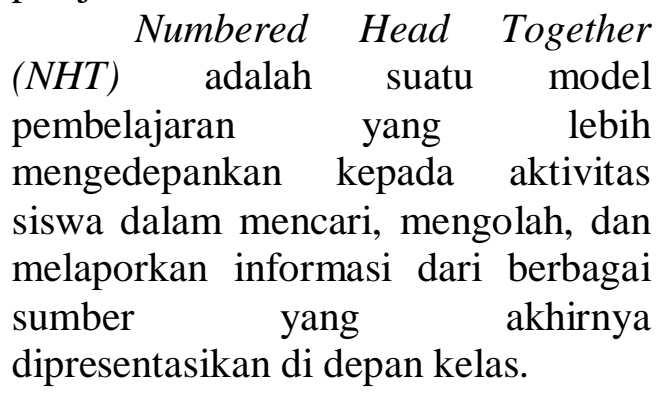

Struktur yang dikembangkan oleh Kagen ini menghendaki siswa belajar saling membantu dalam kelompok kecil dan lebih dicirikan oleh penghargaan kooperatif dari pada penghargaan individual. Ada struktur yang memiliki tujuan umum untuk meningkatkan penguasaan isi akademik dan ada pula struktur yang 
tujuannnya untuk mengajarkan keterampilan sosial (Ibrahim et all, 2007:25). Model pembelajaran Kooperatif tipe NHT adalah bagian dari model pembelajaran kooperatif struktural, yang menekankan pada struktur-struktur khusus yang dirancang untuk mempengaruhi pola interaksi siswa. Struktur Kagan menghendaki agar para siswa bekerja saling bergantung pada kelompokkelompok kecil secara kooperatif.

Pengertian hasil belajar dalam

Kamus Umum Bahasa Indonesia (Depdikbud, 1997) adalah hasil yang telah dicapai dari yang telah dilakukan, dikerjakan, dan sebagainya. Dalam kaitannya dengan belajar, hasil berarti penguasaan pengetahuan atau keterampilan yang dikembangkan oleh guru melalui mata pelajaran, yang lazimnya ditunjukan dengan nilai test atau angka nilai yang diberikan oleh guru. Jadi hasil bermakna pada keberhasilan seseorang dalam belajar atau dalam bekerja atau aktivitas lainnya. Hasil belajar erat hubungannya dengan tujuan belajar.

Hasil belajar merupakan hasil yang diperoleh siswa setelah ia menerima suatu pengetahuan yang berupa angka (nilai). Jadi aktivitas siswa mempunyai peranan yang sangat penting dalam proses belajar mengajar, tanpa adanya aktivitas siswa maka proses belajar mengajar tidak akan berjalan dengan baik, akibatnya hasil belajar yang dicapai siswa rendah.

\section{Metode}

Subyek dalam penelitian tindakan kelas ini adalah siswa kelas XI IPA1 semester genap di SMAN 4 Pontianak tahun 2013/2014 dengan jumlah siswa yaitu 37 orang, terdiri dari 18 siswa laki-laki dan 19 siswa perempuan. Dipilihnya kelas XI IPA1 sebagai subyek penelitian ini karena hasil pengamatan peneliti tampak selama proses pembelajaran rata-rata siswa kurang aktif dan tidak mampu memecahkan permasalahan yang diberikan serta hasil belajar juga masih relatif rendah.

Penelitian tindakan kelas adalah suatu penelitian yang digunakan secara sistematis reflektif terhadap berbagai tindakan yang dilakukan oleh guru sekaligus sebagai peneliti. Penelitian ini dimulai dengan menyusun perencanaan sampai penilaian terhadap tindakan nyata di dalam kelas berupa kegiatan belajarmengajar. Hal ini diharapkan tidak ada lagi permasalahan yang menjadi kendala di dalam pembelajaran. Penelitian tindakan kelas ini sangat diharapkan dapat bermanfaat bagi guru dalam rangka peningkatan hasil belajar di kelas, serta sebagai solusi dari masalah di kelas.

Bentuk penelitian yang digunakan pada penelitian ini adalah penelitian tindakan kelas model Kurt Lewin ( 1946) yang terdiri dari empat komponen, yaitu: perencanaan (planning), tindakan (acting), pengamatan (observing), dan refleksi (reflekting).

Penelitian tindakan kelas ini dilaksanakan di SMA Negeri 4 Pontianak pada semester genap tahun pelajaran 2013 - 2014 mulai 03 Januari s.d 20 Maret 2014. Adapun tahapan-tahapan yang dilalui dalam penelitian tindakan kelas ini adalah sebagai berikut :

A. Siklus I

1. Perencanaan 
Pada tahap perencanaan ini dilakukan berbagai persiapan seperti (a) identifikasi permasalahan (dokumentasi nilai Biologi siswa Kelas XI IPA 1 Tahun pelajaran 2012 - 2013), data hasil observasi guru selama proses pembelajaran, dan data penilaian tugas siswa. (b) menyusun jadwal pelaksanaan penelitian, (c) menyusun instrumen penelitian yang meliputi lembar wawancara, lembar observasi kolaborator, jurnal harian siswa dan kisi-kisi serta soal ulangan harian. (d) menyiapkan alat dan bahan penelitian seperti perlengkapan presentasi (e) menyusun perangkat pembelajaran seperti silabus, rencana pelaksanaan pembelajaran (RPP) serta menetapkan kriteria ketuntasan minimal (KKM).

2. Pelaksanaan

Pada tahap pelaksanaan tindakan, dilakukan proses pembelajaran sesuai dengan desain tindakan yaitu penerapan model pembelajaran kooperatif tipe NHT meliputi (a) pembentukan kelompok diskusi siswa secara heterogen, (b) penomoran siswa, (c) pengajuan pertanyaan berupa lembar kegiatan siswa untuk diskusi, (d) berpikir bersama untuk menggambarkan dan meyakinkan bahwa setiap anggota tim (kelompok) mengetahui jawabannya, pemberian jawaban, (e) guru menyebut nomor tertentu kemudian siswa yang nomornya sesuai mengacungkan tangan untuk menjawab pertanyaan, (f) siswa yang bernomor sama menanggapi jawaban tersebut, melaksanakan tes. Setelah itu pembelajaran dilanjutkan dengan pembahasan, dan penarikan kesimpulan yang dilakukan oleh guru bersama siswa.

3. Observasi

$$
\text { Pengamatan terhadap }
$$
proses pelaksanaan tindakan kelas dilakukan oleh kolaborator, baik menggunakan instrumen observasi yang telah disediakan maupun secara langsung mencatat setiap kejadian yang teramati selama proses pembelajaran. Hasil observasi direkam dan didokumentasikan sebagai data penelitian.

4. Refleksi

Pada akhir setiap siklus tindakan, diadakan refleksi terhadap proses pembelajaran, berdasarkan data observasi , data hasil wawancara dan data pada jurnal harian siswa. Sedangkan data penilaian siswa berasal dari nilai presentasi, nilai poster lingkungan dan nilai ulangan harian siswa. Dengan hasil refleksi ini peneliti dapat melihat apakah tindakan yang dilakukan dalam penelitian ini dapat meningkatkan efektifitas proses pembelajaran yang secara berkelanjutan akan meningkatkan pula prestasi belajar siswa.

B. Siklus II

Tindakan pada siklus II dilaksanakan berdasarkan temuantemuan hasil refleksi siklus I. Karena karakteristik materi hampir sama dan model pembelajaran yang sama, maka tahapan-tahapan penelitian tindakan kelas yang dilakukan tetap sama namun dengan berbagai perbaikan.

1. Perencanaan

Berdasarkan temuan pada tindakan siklus I, pada tahap perencanaan siklus II dilakukan 
berbagai persiapan seperti (a) identifikasi permasalahan yaitu mengatasi kekurangaktifan antar anggota kelompok baik dalam melakukan diskusi kelompok, maupun dalam mempresentasikan hasil diskusi kelompok. Dengan demikian perencanaan tindakan suklus II diawali dengan pembentukan kelompok baru berdasarkan masukan dari siswa, (b) menyusun instrumen penelitian berupa kisi-kisi serta soal ulangan harian. Sesuai materi siklus II (c) menyiapkan alat dan bahan penelitian seperti perlengkapan presentasi.

2. Pelaksanaan

Berdasarkan temuan pada siklus I, diperoleh data bahwa nilai siswa untuk aspek psikomotorik masih belum maksimal. Sebagai upaya perbaikan, maka pada tindakan siklus II dilakukan hal sebai berikut: (a) Sebelum KBM dimulai diberikan beberapa penjelasan tentang strategi berdiskusi dengan pembagian tugas yang jelas, strategi mengamati, menganalisis data dan mendiskusikan hasil pengamatan; (b) Diinstruksikan kepada siswa, agar mempersiapkan semua bahanbahan pendukung terutama bahan presentasi sehingga pembelajaran menjadi efektif dan efisien.

3. Observasi

Pengamatan terhadap proses pelaksanaan tindakan kelas pada siklus II , dilakukan oleh kolaborator, baik menggunakan instrumen observasi yang telah disediakan maupun secara langsung mencatat setiap kejadian yang teramati selama proses pembelajaran. Hasil observasi direkam dan didokumentasikan sebagai data penelitian.

4. Refleksi

Pada akhir siklus II, diadakan refleksi terhadap proses pembelajaran, berdasarkan data observasi, data hasil wawancara dan data pada jurnal harian siswa. Sedangkan data penilaian siswa berasal dari nilai presentasi, nilai poster lingkungan dan nilai ulangan harian siswa. Dengan hasil refleksi ini peneliti dapat melihat apakah tindakan yang dilakukan dalam siklus II ini dapat mengatasi permasalahan yang ditemukan selama pelaksanaan tindakan siklus I serta melihat apakah hasil belajar siswa pada siklus II sudah mencapai indikator kertercapaian yang ditentukan. Jika belum mencapai indikator ketercapaian yang ditetapkan maka penelitian tindakan kelas ini dilanjutkan lagi pada siklus III dengan berbagai perbaikan pada hasil temuantemuan di siklus II.

C. Siklus III

Siklus III dilaksanakan berdasarkan hasil refleksi pada pembelajaran siklus II yang dapat dikatakan telah memadai. Pelaksanaan siklus III tidak jauh berbeda dengan siklus I dan II. Siklus III merupakan tindak lanjut dari hasil yang peroleh pada siklus II. Kendalakendala yang terjadi pada siklus II khususnya pada kemampuan mengajar guru tidak terlihat lagi pada siklus III. Guru telah secara runtut melaksanakan skenario pembelajaran. Guru juga telah memotivasi siswa untuk meningkatkan pembelajaran.

Untuk pembelajaran pada Siklus III ini dilakukan beberapa penyempurnaan dalam strategi 
pembelajaran antara lain: (1) sebelum KBM dilaksanakan, peneliti dan kolaborator merencanakan menambah penggunaan media pembelajaran interaktif sehingga siswa tidak merasa bosan dalam proses pembelajaran; (2) pada siklus III pembelajaran dilaksanakan di laboratorium biologi, yang suasana ruang lebih kondusif, bersih serta memiliki sarana prasarana yang medukung materi pembelajaran biologi sistem pencernaan makanan manusia.

Data untuk penelitian tindakan kelas ini berasal dari penilaian tes dan nontes. Penilaian tes berupa ulangan harian/tes teretulis untuk mengungkap kemampuan kognitif siswa, kemampuan psikomotorik dan penilaian raah afektif. Penilaian nontes berupa panduan wawancara, panduan observasi, jurnal harian siswa untuk melihat perubahan perilaku siswa selama proses pembelajaran. Secara lebih rinci, alat penilaian atau instrumen dalam penelitian ini berupa: 1) Lembar observasi, yang diisi oleh kolaborator untuk mengetahui kondisi, sikap, respons dan tingkat aktifitas siswa dan guru selama proses pembelajaran 2) Lembar wawancara. Lembar wawancara digunakan oleh peneliti

\section{Hasil dan Pembahasan}

Hasil penellitian tindakan kelas yang dilakukan pada kelas XI IPA 1 SMA Negeri 4 Pontianak tahu pelajaran 2013-2014 menunjukkan bahwa penerapan model pembelajaran kooperatif tipe NHT dapat meningkatkan aktivitas dan hasil belajar siswa dalam pembelajaran biologi materi sistem pencernaan makanan. Adapun peningkatan untuk mengetahui tanggapan siswa tentang pelaksanaan proses pembelajaran.

3) Instrumen penilaian hasil belajar (Butir soal ulangan harian) sebagai indikator keberhasilan proses pembelajaran untuk mengungkap kemampuan kognitif siswa. 4) Intrumen penilaian presentasi siswa untuk mengungkap kemampuan psikomotorik siswa 5) Instrumen penilaian untuk mengungkap aspek afektif siswa. 6) Alat-alat dokumentasi, seperti kamera dan tape recorder, sebagai perekam data-data penelitian yang dibutuhkan.

Analisis dan pengolahan data yang digunakan peneliti dalam penelitian ini adalah teknik kuantitatif dan kualitatif. Hasil kegiatan observasi dan hasil wawancara akan memberikan gambaran mengenai kesulitan yang dialami guru dan siswa dalam pembelajaran. Temuan tersebut diharapkan sebagai gambaran dalam menemukan solusi terhadap kesulitan pembelajaran, agar guru dapat menerapkan model pembelajaran NHT dalam pembelajaran di dalam kelas, sehingga terjadi peningkatan aktivitas dan hasil belajar siswa dalam pembelajaran biologi.

aktivitas dan hasil belajar siswa dalam pembelajaran biologi dengan penerapan model pembelajaran kooperatif tipe NHT ini meliputi:

Hasil tindakan siklus I berupa data aktivitas belajar siswa penilaian selama proses pembelajaran belangsung dan data hasil belajar siswa yang diperoleh dari nilai ulangan harian. Secara rinci data tindakan siklus I disajikan pada Tabel 1 dan Tabel 2. 
Tabel 1. Persentase Aktivitas Belajar Siswa dalam Pembelajaran dengan Menggunakan NHT pada materi Sistem Pencernaan Makanan Siklus I.

\begin{tabular}{|c|c|c|c|}
\hline No & Aspek Aktivitas yang diamati & Frekuensi & Persentase \\
\hline 1 & $\begin{array}{l}\text { Keberanian siswa dalam bertanya dan } \\
\text { mengemukakan pendapat }\end{array}$ & 13 & 35,14 \\
\hline 2 & $\begin{array}{l}\text { Motivasi dan kegairahan dalam proses belajar } \\
\text { (meyelesaikan tugas mandiri atau tugas } \\
\text { kelompok) }\end{array}$ & 14 & 37,84 \\
\hline 3 & Kerjasama dalam kelompok & 13 & 35,14 \\
\hline 4 & $\begin{array}{l}\text { Kreativitas belajar siswa (membuat catatan, } \\
\text { ringkasan) }\end{array}$ & 15 & 40,54 \\
\hline 5 & $\begin{array}{l}\text { Interaksi dan komunikasi dengan sesama siswa } \\
\text { selama pembelajaran (dalam kerja kelompok) }\end{array}$ & 16 & 42,24 \\
\hline 6 & $\begin{array}{l}\text { Interaksi dan komunikasi dengan guru selama } \\
\text { kegiatan }\end{array}$ & 13 & 35,14 \\
\hline 7 & $\begin{array}{lcr}\text { Partisipasi } & \text { siswa } & \text { dalam } \\
\text { pembelajaran } & \text { (memperhatikan } & \text { dan } \\
\text { mendengarkan, ikut melakukan } & \text { kegiatan } \\
\text { kelompok, selalu mengikuti petunjuk guru). }\end{array}$ & 13 & 35,14 \\
\hline & Rerata & 14 & 37,84 \\
\hline
\end{tabular}

Tabel 2. Hasil Belajar Siswa dalam Pembelajaran Menggunakan Model NHT Pada Siklus I.

\begin{tabular}{rlc}
\hline No & \multicolumn{1}{c}{ Kategori } & Persentase \\
\hline 1 & Rata-rata kelas & 70,00 \\
\hline 2 & Ketuntasan Klasikal & 40,54 \\
\hline 3 & Ketidaktuntasan Klasikal & 59,46 \\
\hline
\end{tabular}

Dari kedua tabel di atas diketahui bahwa aktivitas belajar dan hasil belajar biologi pada materi sistem pencernaan makanan di siklus I masih belum mencapai kriteria yang ditentukan. Di mana jumlah siswa yang aktif dalam pembelajaran biologi dengan menggunakan model pembelajaran kooperatif tipe NHT hanya sebanyak 14 siswa atau $37,84 \%$ saja dari jumlah siswa di kelas XI IPA1 sebanyak 37 siswa. Sedangkan untuk hasil belajar yang diperoleh siswa pada siklus I, dengan rata-rata kelas hanya 70,00 sedangkan kriteria ketuntasan minimal sebesar 78,00 dan siswa yang tuntas sebanyak 15 siswa atau 40,54\%; yang tidak tuntas sebanyak 22 siswa atau 59,46\%. Sehingga diperlukan perbaikan dan penyempurnaan pada langkahlangkah pembelajaran yang akan dilaksanakan pada siklus berikutnya.

Hasil tindakan pada siklus II dimana siklus ini dilaksanakan berdasarkan refleksi pada siklus I yang belum mencapai indikator pencapaian. Siklus II merupakan refleksi atau tindak lanjut dari hasil yang peroleh pada siklus I. 
Selanjutnya dilakukan beberapa penyempurnaan yang bertujuan untuk : 1) lebih meningkatkan aktivitas belajar siswa; dan 2) meningkatkan hasil belajar siswa.

Untuk pembelajaran pada Siklus II ini dilakukan beberapa penyempurnaan dalam strategi pembelajaran antara lain:

1. Sebelum kegiatan belajar mengajar dimulai, siswa diberikan beberapa penjelasan tentang strategi berdiskusi dengan pembagian tugas yang jelas, strategi mengamati, menganalisis data dan mendiskusikan hasil pengamatan;

2. Diinstruksikan kepada siswa, agar mempersiapkan semua bahanbahan pendukung terutama bahan presentasi sehingga pembelajaran menjadi efektif dan efisien.

Dari hasil observasi pelaksanaan tindakan pada siklus II diperoleh data persentase aktivitas belajar dan hasil belajar siswa yang dapat dilihat dengan jelas pada tabel berikut:

Tabel 3. Persentase Aktivitas Belajar Siswa dalam Pembelajaran dengan Menggunakan NHT pada materi Sistem Pencernaan Makanan Siklus II.

\begin{tabular}{|c|c|c|c|}
\hline No & Aspek Aktivitas yang diamati & Frekuensi & Persentase \\
\hline 1 & $\begin{array}{l}\text { Keberanian siswa dalam bertanya } \\
\text { mengemukakan pendapat }\end{array}$ & 25 & 67,57 \\
\hline 2 & $\begin{array}{l}\text { Motivasi dan kegairahan dalam proses belajar } \\
\text { (meyelesaikan tugas mandiri atau tugas } \\
\text { kelompok) }\end{array}$ & 26 & 70,27 \\
\hline 3 & Kerjasama dalam kelompok & 25 & 67,57 \\
\hline 4 & $\begin{array}{l}\text { Kreativitas belajar siswa (membuat catatan, } \\
\text { ringkasan) }\end{array}$ & 26 & 70,27 \\
\hline 5 & $\begin{array}{l}\text { Interaksi dan komunikasi dengan sesama siswa } \\
\text { selama pembelajaran (dalam kerja kelompok) }\end{array}$ & 26 & 70,27 \\
\hline 6 & $\begin{array}{l}\text { Interaksi dan komunikasi dengan guru selama } \\
\text { kegiatan }\end{array}$ & 29 & 78,38 \\
\hline 7 & $\begin{array}{lcr}\text { Partisipasi } & \text { siswa } & \text { dalam } \\
\text { pembelajaran } & \text { (memperhatikan } & \text { dan } \\
\text { mendengarkan, ikut melakukan } & \text { kegiatan } \\
\text { kelompok, selalu mengikuti petunjuk guru). }\end{array}$ & 26 & 70,27 \\
\hline & Rerata & 26 & 70,27 \\
\hline
\end{tabular}

Tabel 4. Hasil Belajar Siswa dalam Pembelajaran Menggunakan Model NHT Pada Siklus II.

\begin{tabular}{rlc}
\hline No & \multicolumn{1}{c}{ Kategori } & Persentase \\
\hline 1 & Rata-rata kelas & 77,19 \\
\hline 2 & Ketuntasan Klasikal & 51,35 \\
\hline 3 & $\begin{array}{l}\text { Ketidaktuntasan } \\
\text { Klasikal }\end{array}$ & 48,65 \\
\hline
\end{tabular}


Dari data yang tertera pada tabel 3 dan tabel 4 di atas diketahui bahwa aktivitas belajar dan hasil belajar biologi pada materi sistem pencernaan makanan di siklus II mengalami peningkatan dibandingkan dengan hasil ketercapaian pada siklus I, walaupun masih belum mencapai kriteria ketuntasan minimal yang ditentukan. Di mana jumlah siswa yang aktif dalam pembelajaran biologi dengan menggunakan model pembelajaran kooperatif tipe NHT hanya sebanyak 26 siswa atau 70,27\% saja dari jumlah siswa di kelas XI IPA1 sebanyak 37 siswa. Sedangkan untuk hasil belajar yang diperoleh siswa pada siklus II, dengan rata-rata kelas hanya 77,19 sedangkan kriteria ketuntasan minimal sebesar 78,00 dan siswa yang tuntas sebanyak 19 siswa atau $51,35 \%$; yang tidak tuntas sebanyak 18 siswa atau $48,65 \%$. Sehingga diperlukan perbaikan dan penyempurnaan pada langkahlangkah pembelajaran yang akan dilaksanakan pada siklus berikutnya.

Tindakan yang dilakan pada siklus III dilaksanakan berdasarkan refleksi pada siklus II yang belum mencapai indikator pencapaian. Siklus III dilaksanakan berdasarkan hasil refleksi pada pembelajaran siklus II yang dapat dikatakan telah memadai. Pelaksanaan siklus III tidak jauh berbeda dengan siklus I dan II. Siklus III merupakan tindak lanjut dari hasil yang peroleh pada siklus II. Kendala-kendala yang terjadi pada siklus II khususnya pada kemampuan guru tidak terlihat lagi pada siklus III. Guru telah secara runtut melaksanakan skenario pembelajaran. Guru juga telah memotivasi siswa untuk meningkatkan pembelajaran. Untuk pembelajaran pada siklus III ini dilakukan beberapa penyempurnaan dalam strategi pembelajaran antara lain:

1. Sebelum kegiatan belajar mengajar dimulai, peneliti dan kolaborator merencanakan menambah penggunaan media pembelajaran interaktif sehingga siswa tidak merasa bosan dalam proses pembelajaran;

2. Pada siklus III pembelajaran dilaksanakan di laboratorium biologi, yang suasana ruang lebih kondusif, bersih serta memiliki sarana prasarana yang medukung materi pembelajatan biologi sistem pencernaan makanan manusia.

Dari hasil observasi pelaksanaan tindakan pada siklus III diperoleh data persentase aktivitas belajar dan hasil belajar siswa yang dapat dilihat dengan jelas pada tabel berikut:

Tabel 5. Persentase Aktivitas Belajar Siswa dalam Pembelajaran dengan Menggunakan NHT pada materi Sistem Pencernaan Makanan Siklus III.

\begin{tabular}{clcccc}
\hline No & \multicolumn{3}{c}{ Aspek Aktivitas yang diamati } & Frekuensi & Persentase \\
\hline 1 & $\begin{array}{l}\text { Keberanian siswa dalam bertanya dan } \\
\text { mengemukakan pendapat }\end{array}$ & 33 & 89,19 \\
\hline 2 & $\begin{array}{l}\text { Motivasi dan kegairahan dalam proses belajar } \\
\text { (meyelesaikan tugas mandiri atau tugas } \\
\text { kelompok) }\end{array}$ & 33 & 89,19 \\
\hline 3 & Kerjasama dalam kelompok & 36 & 97,29 \\
\hline
\end{tabular}




\begin{tabular}{clccc}
\hline No & \multicolumn{1}{c}{ Aspek Aktivitas yang diamati } & Frekuensi & Persentase \\
\hline 4 & $\begin{array}{l}\text { Kreativitas belajar siswa (membuat catatan, } \\
\text { ringkasan) }\end{array}$ & 35 & 94,59 \\
\hline 5 & $\begin{array}{l}\text { Interaksi dan komunikasi dengan sesama siswa } \\
\text { selama pembelajaran (dalam kerja kelompok) }\end{array}$ & 34 & 91,89 \\
\hline 6 & $\begin{array}{l}\text { Interaksi dan komunikasi dengan guru selama } \\
\text { kegiatan }\end{array}$ & 36 & 97,29 \\
\hline 7 & $\begin{array}{l}\text { Partisipasi siswa dalam } \\
\text { pembelajaran dandan } \\
\text { mendengarkan, ikut melakukan kegiatan } \\
\text { kelompok, selalu mengikuti petunjuk guru). }\end{array}$ & 37 & 100 \\
\hline \multicolumn{5}{c}{ Rerata } \\
\hline
\end{tabular}

Tabel 6. Hasil Belajar Siswa dalam Pembelajaran Menggunakan Model NHT Siklus III.

\begin{tabular}{rlc}
\hline No & \multicolumn{1}{c}{ Kategori } & Persentase \\
\hline 1 & Rata-rata kelas & 79,32 \\
\hline 2 & Ketuntasan Klasikal & 75,68 \\
\hline 3 & Ketidaktuntasan Klasikal & 24,32 \\
\hline
\end{tabular}

Dari tabel 5 dan tabel 6 diketahui bahwa aktivitas belajar dan hasil belajar biologi pada materi sistem pencernaan makanan di siklus III mengalami peningkatan dibandigkan dengan hasil ketercapaian pada siklus II, dan siklus III telah mencapai kriteria yang ditentukan. Di mana jumlah siswa yang aktif dalam pembelajaran biologi dengan menggunakan model pembelajaran kooperatif tipe NHT hanya sebanyak 35 siswa atau 94,59\% saja dari jumlah siswa di kelas XI
IPA1 sebanyak 37 siswa. Sedangkan untuk hasil belajar yang diperoleh siswa pada siklus III, dengan rata-rata kelas hanya 79,32 sedangkan kriteria ketuntasan minimal sebesar 78,00 dan siswa yang tuntas sebanyak 28 siswa atau $75,68 \%$; yang tidak tuntas sebanyak 9 siswa atau 24,32\%.

Dan pada akhir siklus III juga dilakukan pemberian angket tentang penerapan model pembelajaran kooperatif tipe NHT sebagai refleksi dari siklus III, yang dapat dilihat pada tabel berikut ini:

Tabel 7. Rekapitulasi Pendapat Siswa Tentang Penerapan NHT dalam Pembelajaran Biologi

\begin{tabular}{cccc}
\hline $\begin{array}{c}\text { Pendapat tentang penerapan } \\
\text { NHT dalam Pembelajaran } \\
\text { Biologi }\end{array}$ & Setuju & Ragu-ragu & Tidak Setuju \\
\hline Rekapitulasi Data & $67,72 \%$ & $34,71 \%$ & $0,57 \%$ \\
\hline $\begin{array}{c}\text { Selain itu diketahui bahwa } \\
\text { dari hasil analisis data angket tentang }\end{array}$ & $\begin{array}{c}\text { tanggapan siswa terhadap penerapan } \\
\text { model pembelajaran kooperatif tipe }\end{array}$
\end{tabular}


NHT dalam pembelajaran biologi, sebanyak $64,72 \%$ yang setuju, raguragu $34,71 \%$ dan yang tidak setuju hanya $0,57 \%$. Sehingga dapat disimpulkan bahwa pembelajaran kooperatif tipe NHT sangat diminati oleh siswa saat diterapkan dalam pembelajaran biologi.

Hal ini sesuai dengan pendapat Kunandar, (2010: 277) aktivitas belajar siswa adalah keterlibatan siswa dalam bentuk sikap, pikiran, perhatian, dan aktivitas dalam kegiatan pembelajaran guna menunjang keberhasilan proses belajar mengajar dalam memperoleh manfaat dari kegiatan tersebut. Aktivitas belajar siswa dalam pembelajaran Biologi menggunakan model pembelajaran kooperatif tipe NHT telah berjalan dengan baik. Siswa terlihat lebih aktif dalam pembelajaran dan antusias dalam menjawab pertanyaan yang diberikan oleh guru. Selain itu, siswa juga lebih berani mengemukakan pendapat atau bertanya mengenai materi yang belum dimengerti.

\section{Simpulan dan Saran}

Berdasarkan penelitian tindakan kelas ini dapat diambil simpulan sebagai berikut:

1. Penggunaan model pembelajaran kooperatif tipe NHT pada pembelajaran Biologi dapat meningkatkan aktivitas belajar siswa.

2. Penggunaan model pembelajaran kooperatif tipe NHT pada pembelajaran Biologi dapat meningkatkan hasil belajar dan ketuntasan belajar siswa.

3. Hasil observasi kompetensi kerja ilmiah siswa mengalami peningkatan dari siklus I ke siklus
III mencapai kategori sangat baik, angket pendapat siswa menunjukkan bahwa siswa senang dengan model pembelajaran yang diterapkan oleh peneliti.

\section{Saran}

Sehubungan dengan hasil penelitian tindakan kelas yang penulis lakukan, kiranya dapat memberikan saran sebagai berikut:

1. Kepada siswa; para siswa hendaknya lebih meningkatkan kerjasamanya dalam kegiatan pembelajaran, terutama dalam mengerjakan tugas-tugas kelompok yang diberikan oleh guru. Dengan begitu maka selain akan menimbulkan rasa saling asah, saling asih dan saling asuh di antara siswa juga akan mempermudah upaya pencapaian tujuan pembelajaran di sekolah.

2. Dalam pengajaran biologi, hendaknya guru mengintegrasikan bahan ajar dengan permasalahan yang ada di lingkungan sekitar siswa

3. Dalam pengajaran Biologi, hendaknya guru memilih metode mengajar yang dapat meningkatkan sikap positif siswa terhadap lingkungan

4. Dalam pengajaran biologi hendaknya guru menggunakan berbagai teknik penilaian selain test, sehingga dapat mengungkapkan berbagai kompetensi yang dimiliki siswa.

5. Guru diharapkan lebih kreatif dan inovatif dalam kelas dan mampu mengembangkan penyusunan tugas agar siswa tidak merasa bosan.

\section{Daftar Pustaka}

Anitah, Sri. 2008. Strategi Pembelajaran di SD. Jakarta: Universitas Terbuka. 
BSNP. 2006. Kurikulum Tingkat Satuan Pendidikan. Jakarta: Depdikbud.

Ibrahim, Muslimin, dkk. 2007. Pembelajaran Kooperatif. Surabaya: UNESA University Pres.

Kunandar. 2010. Langkah Mudah Penelitian Tindakan Kelas sebagai Pengembangan Profesi. PT Rajawali Pers. Jakarta.

Lewin K. 1946. Action Research and Minority Problems: Journal of Social Issues, 2(4),34 - 46.
Raka, Joni T. 1980. Strategi Belajar Mengajar. Jakarta : P3LPTK.

Sanjaya, Wina. 2007. Strategi Pembelajaran: Berorientasi Standar Proses Pendidikan. Jakarta: Kencana Prenada Media Group.

Sardiman. 2008. Interaksi dan Motivasi Belajar Mengajar. Jakarta: PT RajaGrafindo Persada. 